\title{
The Graduate Assistant Program at the University of Florida
}

Mr. Grazier, formerly assistant director of libraries, University of Florida, is now associate librarian, Wayne University.

$I^{\mathrm{x}}$ THE SPRING of I95I, the University of Florida Library inserted in the news columns of the several library journals an offer of two graduate assistantships for study leading to a master's or doctoral degree in a subject field other than library science and invited inquiries "especially from librarians or students in library schools. ..." Printed announcements of the assistantships were distributed to some 150 college and university libraries throughout the country. Each year since then, these assistantships have been publicized through the same media, and each year there are questions, both from potential applicants and from other institutions, about this program. Applicants wish to know how long it will take for them to get a degree and what kind of library work is required for the stipend. Fellow librarians have asked how the program has worked out; has it been successful; what is the vocational intent-to list but a few of the queries. In the light of such questions, a brief description of the plan might be of interest to other librarians.

The graduate assistant program began in 1948 when the University Committee on Assistantships approved the library's request for two graduate assistants for the academic year 1948-49, carrying a stipend of $\$ 900$ each. These assistants were sought for the purpose of aiding the Reference and Bibliography Department in preparing bibliographies or in carrying out the bibliographical projects which were too extensive for the current staff to undertake. The assistants were selected from qualified graduate students in the various departments of the university and worked directly with the faculty but under the guidance of the reference librarians. For several years the funds were granted by the University Committee on Assistantships, but in 1950 the procedure was changed so that each unit of the university incorporated its request for graduate assistants in its annual budget; since then, the assistantships have been a part of the university library's budget. Thus, the university administration accepted the fact that the university library as well as the Department of Chemistry deserved the services of graduate assistants, or more specifically, that the compilation of bibliographies was as valuable to the university as the supervision of laboratory experiments.

The next change in the program was the library's effort to discover practicing librarians or library school students who might be interested in these assistantships. The decision to try to allot the award to librarians was based on two assumptions. First, despite the current controversies about the proper education for librarians there is a demand, particularly by special and academic libraries, for subject specialists. Secondly, if academic libraries require subject specialists, it is fitting they make an effort to advance the education of the members of their profession. If recruitment or in-service training are proper activities for libraries, why not direct the support of formal education? Hence, to the original objective 
of the graduate assistant program, that of expanding the bibliographical service of the Reference and Bibliography Department, was added another-to make a contribution to the education of librarians.

There have been one or two minor changes in the program since its inception in 1948. The stipend, the same as offered by other graduate assistantships throughout the university, of $\$ 900$ for I I months service was increased to $\$$ I IOO for II months service, and for the past two years has been \$1200 for nine months of service, an inflationary trend not unique in this decade. The graduate assistants work 15 hours per week which limits their maximum academic program to 12 semester hours, and the minimum amount of time required to complete a master's degree is two semesters plus the summer session. The assistantship may be renewed if the candidate's work progresses satisfactorily. Within the last two years, two more graduate assistantships have been offered, one of which is financed by the College of Physical Education and Health with the understanding that the assistant selected by the library would be assigned to supervise the newly opened Physical Education and Health Reading Room. This was a temporary expedient until the service load of the reading room justified a full-time staff member, and the assistantship will not be offered after this year.

"Has this program been successful?" is the most frequent query posed by our colleagues although a few hint as to what they mean by "successful." An earlier paragraph set forth two objectives of the program: one to expand the bibliographical services of the library, the second and later, to support the training of librarians. A brief appraisal of the program in the light of these objectives may give some clue as to its success.

The bibliographical production of the graduate assistants falls into two categories: bibliographies or selective lists of material for individual instructors or departments of the university, and bibliographical surveys which provide data for library policies and operations.

Examples of the first category include a bibliography on gerontology for the Southern Conference on Gerontology; selective readings for secretaries, stenographers and typists done for Employee Personnel Services; a bibliography on the history of building construction in the United States for an instructor in the College of Architecture and Allied Arts.

Examples of the second category include surveys of specific fields of scholarly publication, and the compilation of lists of desiderata; a cost study of journal duplication made for the University Library Committee; surveys made of titles circulated from the library stacks to determine which additional materials should be moved into the divisional reading rooms.

These examples are a fair cross-section of the work done by graduate assistants. Some of the studies were of such importance that the regular staff would have had to do the job, had no graduate assistants been available; others would have been left undone. Could the library have done this bibliographical work in a more economical way? Three graduate assistants at \$1200 each, produce a salary for a full-time professional staff member who undoubtedly would and could do the kind and amount of work done by the graduate assistants. (A minor digression might be in order here. The \$1200 stipend for nine months at 15 hours per week equals or slightly surpasses our salary of $\$ 3600$ per year for beginning staff members. Simple arithmetic bears out the assertion that the graduate assistantships are not an attempt to exploit young librarians eager to improve their education). The library's original request to the Committee on Assistantships was based on the 
known fact that several instructional departments already were using their graduate assistants to check library holdings, prepare bibliographies, make up reading lists and to do similar routines. The library reasoned that such work could be done more efficiently under the guidance of the Reference and Bibliography Department and that small instructional departments which did not have graduate assistants for these tasks would have a chance to share in such a service if it were provided by a central agency. It is possible that the library's graduate assistants originally were obtained at the expense of graduate assistants in other departments of the University but not at the price of other library personnel.

How successful the plan has been as a contribution to the training of participating librarians poses a more difficult question. Let us assume that in an ideal program there would be a large number of wellqualified applicants; the successful candidates would obtain their advanced degrees and go forth to better paying positions in which they used their new knowledge. If these are acceptable criteria of a successful program, what is the evidence of some four years of the assistantships?

The annual announcements of the assistantships usually bring some several dozen letters asking for application forms or more information about the program. A few inquirers, misreading the announcement, think the University of Florida offers advanced degrees in librarianship, which it does not. A few letters are from non-librarians, who are discouraged from applying. If there is an insufficient number of qualified librarianapplicants, the assistantships are given to graduate students already on the campus. From 1951 through 1954, some 9I inquiries produced 22 bona fide applicants, that is, applicants who filled out necessary papers, sent transcripts to the registrar and applied for admission to the graduate school.

Of these 22 applicants, nine were em- ployed in academic libraries, two in public libraries, and two in school libraries. Seven were enrolled in library schools at the time they applied and one was a gentleman of leisure. The sexes were equally represented, and the median age of the applicants was 28.5. Eighteen of the 22 applicants had, or were currently working on, their first professional degrees; and three of these I 8 had master's degrees in a subject field. Only two of the applicants had undergraduate majors in some field of science, and only two stated that their proposed subject for graduate study was in the natural or physical sciences.

Despite the small number of applicants, the calibre has been high enough to at least offer the assistantships to librarian-applicants. Out of a total of I I assistantships, including renewals, only six have been held by librarians. (Two of the six were renewals; hence, four individuals have held the six assistantships.) There have been several reasons for this. The assistantships have been declined because the applicants had accepted full-time positions, other fellowships, or had changed their minds for "personal reasons." With such a limited supply of applicants, there were times when there were no acceptable alternates; in fact, one year there were no alternates at all, acceptable or otherwise. In several cases, last minute changes of plans unexpectedly vacated assistantships. When no qualified alternates are available, the assistantships are given to on-campus students recommended by their respective departments. The unforeseen will always make it difficult to insure that librarians will hold the assistantships, and any number of good applicants could not change this situation. The fact does remain, however, that there have been several years in which the shortage of applicants has resulted in granting assistantships to non-librarian graduate students. In short, the criterion of a "large number of qualified applicants" has not been met. 
The second suggested criterion for a successful program was that the applicants would "obtain their advanced degrees and go forth to better paying positions in which they used their new knowledge." Of the four librarian-graduate assistants, three originally registered for a master's degree while the fourth began a doctoral program. Two of the graduate assistants came directly from library schools; one had two years' experience in a public library and another two years' experience in a college library. Graduate assistants $\mathrm{A}$ and $\mathrm{B}$ have completed their master's work ; graduate assistants $\mathrm{C}$ and $\mathrm{D}$ are working on their master's and doctoral degrees, respectively. The two librarians who finished their degrees, however, have not exactly "gone forth...." Graduate assistant A, upon completion of his year's work, accepted a position on the library staff. In the meantime he had a novel published and recently resigned from the staff to accept a teaching position in the Humanities Division of our University College. Graduate assistant B decided to continue work on his doctoral degree and accepted a teaching fellowship in the English Department. Graduate assistant C interrupted her course work to accept a fulltime position for one summer and plans to accept a full-time appointment on the staff while she works on her master's thesis. Graduate assistant D, currently on a doctoral program, interrupted his course work to take a full-time position, then resigned to continue his doctorate.

None of the graduate assistants abandoned their study programs, although three of the four interrupted their course work to take temporary full-time positions. The two graduate assistants who completed their degrees, however, are using their "new knowledge" in fields other than librarianship. In the light of these examples, it may behoove a university library not to get too good librarians for the assistantships. These seem to awaken the predatory instincts of our teaching colleagues. The graduate assistant program may improve the education of librarians; but in the limited cases reviewed, it is a moot question as to which profession will benefit.

Such meager data as provided by four years' experience would indicate that the University of Florida's experiment fell short of the ideal program to achieve the second objective-that of contributing to the education of librarians. There have not been enough well-qualified librarian-applicants to fill the assistantships, and neither of the graduate assistants who completed their degrees have returned to the field as better trained librarians.

Yet the plan may have several beneficial by-products which would compensate for its indifferent "success." While the program was intended to further the training of academic librarians by supporting their formal study, it is possible that it has improved their professional competency through their work assignments. Several of the assistants have testified that they have regarded their work experiences valuable as professional education. But it should be admitted that the evidence on this point is contradictory. While several of the graduate assistants believed their duties "educational," the others stated that they would have preferred a greater variety of tasks which might have enlarged their professional knowledge or skills. They criticized the fact that some of the assignments failed to take advantage of their professional skills. To avoid overburdening the graduate assistants with professional responsibilities and consequently interfering with their studies, the library may have erred in the other direction. Theoretically, of course, the assistantships could be combined with a modified form of inservice training, but to date the assignments of the graduate assistants have been determined primarily by the projects to be done and not by professional improvement.

An unexpected advantage to the library 
has been the readiness of the graduate assistants to take short-term appointments to fulltime positions on the staff, thus minimizing the dislocations of service which normally result from staff vacancies. There have been five different positions in which the graduate assistants have worked as regular or interim appointees for staff members who have resigned or taken leaves of absence. Short-term vacancies are particularly difficult to fill and the graduate assistants, possessing some familiarity with the library and being already in a state of professional flux, are "naturals" as replacements. Needless to say, no pressure was exerted upon the graduate assistants to take these positions and such appointments have been made only when mutually desirable to both the library and the graduate assistant. The library, however, has had the opportunity of evaluating the graduate assistant as a potential staff member, and when one offers his candidacy the library can accept or reject with a confidence not merited when the appraisal is based on the usual credentials.

In reviewing our experiment with graduate assistants, I am not certain that I could agree with several applicants who highly commended the program and thought that other academic libraries should follow this example. The limited experience of one university library offers no conclusive evidence, but it at least hints that there is no great need for such a program in librarian- ship. Another library might be flooded with applicants, but I suspect that there are certain factors in library education and the economics of librarianship which would limit the supply of applicants regardless of the institution offering assistantships. I would guess, for example, that a goodly number of the librarians who believe in the need or worth of advanced subject study are currently in academic libraries where they can do graduate work while continuing their full-time professional career. How certain can a librarian be that the advanced degree in a subject field will repay the necessary investment of time and money? Libraries may desire or need subject specialists, but until such demands are formally identified in terms of educational qualifications and higher salaries, few librarians will probably invest in such preparation. In the Library Quarterly of January, 1955, Dean Lester Asheim of the University of Chicago Graduate Library School shrewdly analyzed some of the problems of library education, and until some of these more complex issues are resolved, there seems to be little need for university libraries to undertake any comprehensive plans for graduate assistantships with the object of improving professional training. Libraries may find them useful expedients for expanding certain services, for providing ready sources for staff replacements-but they may have to be justified only in such terms.

\section{Documentation Conference}

A three-day conference on "The Practical Utilization of Recorded Knowledge" will be held on January 16-18, I956 at Western Reserve University. This conference will be co-sponsored by the School of Library Science at Western Reserve and other organizations including ALA, SLA, John Crerar Library, Lehigh University, American Society for Metals, Case Institute of Technology and the New Jersey Law Institute. More than 30 experts will discuss problems facing all librarians today in the processing, dissemination and utilization of the constantly increasing volume of recorded information in the fields of chemistry, law, medicine, metals, military decisions, patents, physics and others.

Send registrations to Jesse H. Shera, School of Library Science, Western Reserve University, Cleveland 6, Ohio. The fee is $\$ 10.00$ (students, $\$ 2.50$ ). Preprints of review papers prepared by the pre-conference committees will be sent to registrants. 